\title{
Towards a Better Understanding of Negotiation: Basic Principles, Historical Perspective and the Role of Emotions
}

\author{
Konstantina Prassa, Anastassios Stalikas \\ Department of Psychology, Panteion University, Athens, Greece \\ Email:konstant_prassa@hotmail.com
}

How to cite this paper: Prassa, K., \& Stalikas, A. (2020). Towards a Better Understanding of Negotiation: Basic Principles, Historical Perspective and the Role of Emotions. Psychology, 11, 105-136. https://doi.org/10.4236/psych.2020.111008

Received: December 12, 2019

Accepted: January 7, 2020

Published: January 10, 2020

Copyright $\odot 2020$ by author(s) and Scientific Research Publishing Inc. This work is licensed under the Creative Commons Attribution International License (CC BY 4.0).

http://creativecommons.org/licenses/by/4.0/

\section{(c) (i) Open Access}

\begin{abstract}
Negotiation, as a form of interpersonal interaction, is essential in any context as it is the means individuals use for managing conflict and accomplishing their objectives. The purpose of this article is to review the current negotiation literature and highlight the significance and pervasive effects of emotions in the negotiation or bargaining process and outcome. Although there has been a broad interest in the study of negotiation, research has mainly focused on the study of the cognitive and rational aspects of the negotiation process while its emotional aspects have been overlooked. Nevertheless, in the past few years, there has been an increasing realization that emotions play a crucial role in negotiation and therefore the study of emotions in negotiation has been embraced by both researchers and academics. This article is organized in three sections. In the first section, the fundamental principles of conflict resolution and negotiation are provided in order to facilitate the understanding of the mixed existing literature which leads to a chaos. In the second section, a historical perspective of negotiation is presented in order to shed light on its evolution over the years. In the third section, the role of emotions in negotiation is highlighted and an emphasis is put on the significance of positive emotions, in an attempt to outline how the discipline of positive psychology can meaningfully contribute to the negotiation field.
\end{abstract}

\section{Keywords}

Negotiation, Positive Emotions, Positive Psychology, Bargaining, Conflict Resolution

\section{Introduction}

Conflict is inevitable and ubiquitous in both personal and organizational life and 
it often causes strong emotional responses to the conflicting parties (Van Kleef, 2008). Conflict is defined as a type of social interaction process between individuals with incompatible values or interests (Mack \& Snyder, 1957; Bernard, 1957; Deutsch, 1973). Several techniques, such as legal procedures, or even violence, can be employed to resolve conflict (Rubin \& Brown, 1975). Nevertheless, the primary and most constructive mechanism for managing conflict is negotiation, which is a form of social exchange used whenever conflict erupts and is defined as the symbolic communication between two or more parties pursuing to reach an agreement on an issue where contradictory interests originally existed (Kimmel et al., 1980). Other definitions consider negotiation as a deliberate interaction between two or more complex social units aiming to define or redefine the terms of their interdependence (Walton \& McKersie, 1965) or as a process aiming to resolve a perceived discrepancy of interests (Pruitt \& Carnevale, 1993; Pruitt, 1998).

In the majority of the literature, "bargaining" is a term used as a synonym for "negotiation", as if they have reference to the same phenomenon. Nevertheless, it is helpful to mention the distinction between the two. Literally, bargaining is more like haggling over price in a "bazaar" setting, so it is negotiation of price alone. It refers to a typical win-lose or competitive form of negotiation where resources are limited and parties act opportunistically as they seek to maximize their benefits at the expense of the other party. On the other hand, negotiation refers to a win-win, problem-solving approach where all parties can end up with equally beneficial outcomes (Stevens, 1958; Ghauri \& Usunier, 2003). Another view supports that while bargaining concerns the interaction between people over some sale or purchase, negotiation refers to the interaction between complex social units (e.g. nations), aiming at resolving multiple issues (Rubin \& Brown, 1975). Since the above-mentioned meanings of the two concepts are considered to be outdated (Ghauri \& Usunier, 2003), in this article, the terms negotiation and bargaining will be treated as interchangeable.

Negotiation has drawn the attention of researchers and practitioners for a long period of time. However, for many years, research had focused on the study of the cognitive aspects of the negotiation process. The emotional aspects in bargaining were not just underestimated but absolutely neglected (Thomas, 1990; Kramer et al., 1993; Brooks \& Schweitzer, 2011). Surprisingly, even concepts such as trust and motives that embody an emotional content had been studied exclusively in terms of strategy (Olekalns \& Druckman, 2014). Emotion was considered to be an obstacle to an effective negotiation outcome while rationality was considered as more appropriate, and neutral emotions expressed by the use of the proverbial impassive "poker face" were strongly suggested (Gibson \& Schroeder, 2002).

Only recently negotiation researchers have shifted their attention from the procedural, cognitive and rational processes to the emotional ones, in an attempt to understand negotiation more fully (e.g. Barry, Fulmer, \& Van Kleef, 2004; 
Kopelman, Rosette, \& Thompson, 2006; Thompson, Nadler, \& Kim, 1999; Allred, 1999; Sinaceur \& Tiedens, 2006; Shapiro, 1991; Baron, 1990; Barry \& Oliver, 1996; Morris \& Keltner, 2000; Shapiro \& Bies, 1994; Lawler \& Yoon, 1995; Barry, 1999). Over the past few years, the influence of emotions and affective components in negotiation has been highlighted (Kumar, 1997) as it has become apparent that rational thought is critical but it cannot operate in the absence of emotions, and vice versa (Callahan, 1988). As Davidson \& Greenhalgh (1999) suggest, when two individuals have different opinions about an issue but neither of them has an emotional reaction, there will be no negotiation.

The purpose of this article is: a) to review the relevant literature and highlight the fundamental principles of conflict resolution and negotiation, b) to present a historical perspective of negotiation, and c) to emphasize the role of emotions, and especially the impact of positive emotions on the negotiation process and outcomes.

\section{Basic Principles of Negotiation}

Since conflict is omnipresent, it can occur between individuals, groups, organizations or nations (Van Kleef \& Côté, 2018). For this reason, negotiation has been studied from several perspectives, including the psychological (e.g. Barry \& Oliver, 1996), the economic (e.g. Tversky \& Kahneman, 1981), the collective (e.g. Walton \& Mc Kersie, 1965), and the diplomatic or international perspective (e.g. Adler, Graham, \& Gehrke, 1987).

Negotiations can take several forms. They can be conflict management or transactional negotiations. They may concern simple daily interactions and disagreements, complex organizational issues, legal disputes or even issues capable of leading to wars. They can take place between two people discussing one issue, or they may involve multiple topics, multiple parties or several people acting on behalf of a constituency. They can be short or long-lasting and they may refer to face-to-face or virtual interactions. Nonetheless, regardless the type of negotiation, they all share a common element: the desire of the parties involved to cooperate so as to avoid impasse and reach an agreement and to compete in order to maximize their outcomes (Komorita \& Parks, 1995; Deutsch, 1973).

The theoretical goal of the negotiation study is to enable individuals to foresee the outcomes of the bargaining process, while its applied goal is to facilitate individuals negotiate in a more effective way (Bazerman, 1986; Raiffa, 1982). The principal features of negotiation are that 1) participants consider their interests as conflicting, 2) communication is feasible, 3) several alternative solutions are possible, 4) individuals have the right to make provisional offers and counter-offers, and 5) offers are not final and binding neither determine the outcome until they are accepted by both parties (Schelling, 1960; Chertkoff \& Esser, 1976). The basic components of negotiation are: 1) the parties that are the individuals (or a group of people sharing common interests) who participate in it, 2) their interests that express their preferences, 3) the process that describes the interac- 
tion, communication and relationship between the parties as well as the bargainers' behaviors, cognitions and motivations, and 4) the outcome that is the product of the bargaining process (Thompson \& Hastie, 1990a; Walton \& McKersie, 1965). While the parties and the interests are quite explicit and clear, the negotiation process and outcome are extremely complex and therefore should be explained and analyzed in more depth.

Negotiation process. The structure of the negotiation process depends on the degree of conflict that exists between parties' interests. Pure conflict, also known as fixed-sum or win-lose or value claiming or purely distributive bargaining, refers to situations where parties' interests are absolutely conflicting and perfectly negatively correlated and thus bargainers' primary motivation is to maximize their utility or their share of fixed-sum payoffs. At the very opposite end, there are pure coordination situations that describe negotiations where bargainers' interests are totally compatible. Nevertheless, most negotiation situations are not classified into any of the above categories but into a third one, variable-sum or win-win or value creation or integrative bargaining, where parties' interests are neither completely opposed and purely competitive nor completely compatible, and the gains of one party do not represent equal losses for the other party. Integrative negotiation follows a joint problem-solving and information sharing format and gives individuals the opportunity to achieve a "bigger pie" and increase the size of their gains (Thompson, 1990; Pruitt \& Rubin, 1986; Raiffa, 1982, Walton \& McKersie, 1965; Lewicki, Weiss, \& Lewin, 1992; Lewicki, Saunders, \& Barry, 2006; Pruitt \& Lewis, 1977).

Negotiation outcome. As far as the negotiation outcome is concerned, it can be either the impasse, when the bargainers fail to reach a mutually accepted agreement, or the agreement between the parties (Thompson, 1990).

Integrative negotiation agreement. In bargaining situations, the agreement is considered to be integrative, efficient or Pareto optimal when it satisfies the interests of all parties involved and there is not any other possible alternative that could benefit one or both parties while at the same time not hurting any of them (Pareto, 1935; Nash, 1950). An illustrative example to comprehend Pareto optimality is a story recounted by Fisher and Ury (1981). Two sisters fighting for a single orange, decided to resolve their dispute by cutting it in half. After a while, they realized that one of them just needed the juice while the other wanted the rind. In this case, cutting the orange in half cannot be considered as Pareto efficient, since another possible solution could have maximized both sisters' outcomes; one could have received the juice and the other all of the rind. Unfortunately, in the real world, not many bargainers manage to reach Pareto-optimal outcomes regularly (Thompson \& Hastie, 1990b).

Distributive negotiation agreement. The distributive aspect of bargaining refers to the way individuals choose to divide resources and can be understood through the classic ultimatum game. The ultimatum bargaining game is the most popular instrument used in negotiation research and was described by 
Güth, Schmittberger and Schwarze (1982). In fact, it is a "take it or leave it" experiment during which a player, called the proposer, is given the opportunity to split a fixed amount of money with another player, called the responder. Once the proposer communicates his decision to the responder, the latter has the option to either reject it, if the deal is perceived as unfair, or to accept it. In the first case, both players receive nothing, while if the responder accepts it the amount of money is split as per the proposal and the distributive aspect of the bargaining process is the proportion of the initial amount that each negotiator gets. Although the game's structure seems to be quite simple and easy to understand, nevertheless, the psychological mechanisms underlying the players' decisions are both complex and diverse.

Negotiation may result to both economic outcomes, which describe the financial elements gained or lost, and subjective or social-psychological outcomes that refer to the perceptions and feelings about the bargaining situation, the opponent, the self and the instrumental outcomes. The negotiators' satisfaction, the relationship between the parties, and their willingness to repeat the process with the same opponent in the future are some examples of the social-psychological outcomes which may result from negotiation (Curhan et al., 2006). Economic outcomes can influence social-psychological outcomes and vice versa (Allport, 1955; Thompson, 1990; Thompson \& Hastie, 1990a).

One of the most commonly investigated social-psychological outcomes resulting from negotiation is negotiators' subjective value $(S V)$ that is defined as the "social, perceptual, and emotional consequences of a negotiation" (Curhan, Elfenbein, \& Xu, 2006: p. 494). The concept of subjective value incorporates four factors, 1) instrumental $S V, 2)$ self $S V, 3)$ process $S V$ and 4) relationship $S V$ while there is also the 5) global $S V$ representing an integrative framework. Instrumental SV describes the subjective perception that the economic negotiation outcome was beneficial for the individual, self SV refers to one's satisfaction resulting from the belief that his behavior was appropriate, process SV comprises his perception that was treated fairly, and relationship SV includes trust and positive impressions that enhance the willingness for future interaction. Process SV together with relationship SV form the broader construct of rapport (Curhan, Elfenbein, \& Xu, 2006) that describes the mutual positivity and interest (TickleDegnen \& Rosenthal, 1990).

Studies have shown that negotiators who have succeeded instrumentality in a past negotiation feel more confident and motivated to repeat it in the future (Sullivan, O'Connor, \& Burris, 2006). In addition, individuals who feel satisfied with the process and the relationship can evoke same in others and are more willing to compromise with counterparts they know (Druckman \& Broome, 1991; O'Connor et al., 2005). So, subjective value is objectively beneficial in negotiation (Curhan, Elfenbein, \& Eisenkraft, 2010).

\section{Historical Perspective of Negotiation}

Negotiation research has been influenced by several disciplines, including social 
psychology, cognitive psychology, sociology, communication studies, political science, organizational behavior, law, management, mathematics, and economics (Thompson, Wang, \& Gunia, 2010). As a result, there is an impressive body of empirical findings that span several decades and along with the numerous theoretical frameworks and the great variety of terminologies used, they make negotiation field one of the most complex and challenging ones.

Throughout the $1960 \mathrm{~s}$ and $1970 \mathrm{~s}$ the study of negotiation was a field within the domain of social psychology (Druckman, 1977; Pruitt, 1981). During that period, negotiation study primarily focused on two areas of research: a) individual differences of negotiators such as demographic (e.g. gender) and personality (e.g. Machiavellianism) factors, and b) situational or contextual features (e.g. power) that facilitate or hinder the negotiation process (Rubin \& Brown, 1975; Siegel \& Fouraker, 1960; Kelley, 1966; Deutsch, 1973; Druckman, 1968; Morley \& Stephenson, 1977; Neale \& Bazerman, 1992).

\section{1) Individual differences}

Since bargaining is an interpersonal activity, it seems reasonable that negotiators' personal characteristics should have a significant impact on their performance (Bazerman, Curhan, \& Moore, 2001). Nonetheless, despite the countless investigations that have been conducted, individual differences including demographics and personality variables have not been found to explain much variance in negotiation behavior and outcomes (Rubin \& Brown, 1975; Thompson, 1998; Lewicki et al., 1994; Pruitt \& Carnevale, 1993), although supporters of their predicting power still exist (e.g. Barry \& Friedman, 1998). One of the factors that have been extensively studied is gender (e.g. Babcock \& Laschever, 2003; Watson, 1994; Kolb \& Williams, 2000; Kray et al., 2002; Deal, 2000; Major et al., 1984), which is one of the most enduring and controversial issues in negotiation research.

Gender. Across a plethora of studies, there has been inconsistent evidence regarding the influence of gender on bargaining performance (Lewicki, Litterer, Minton, \& Saunders, 1994). Most of the research findings have reported that women a) perceive and experience conflict and negotiation in a different way than men (e.g. Stevens et al., 1993; Stuhlmacher \& Walters, 1999; Gerhart \& Rynes, 1991; Gilkey \& Greenhalgh, 1984; Pinkley, 1990; Zechmeister \& Druckman, 1973), b) use more cooperative strategies (Walters et al., 1998), c) reach more unfavorable agreements (e.g. Dalton \& Todor, 1985; Dalton et al., 1987), d) hesitate to initiate negotiations (Small et al., 2007; Babcock et al., 2006; Bowles et al., 2007), e) agree on lower starting salaries (Gerhart \& Rynes, 1991), and f) they typically achieve worse negotiation outcomes (Stuhlmacher \& Walters, 1999; Kray et al., 2001).

Although these findings have been explained in terms of power and status differences between men and women (Watson, 1994; Watson \& Hoffman, 1996; Bowles, Babcock, \& Lai, 2007; Amanatullah \& Morris, 2010; Bowles, Babcock, \& MacGinn, 2005; Miles \& Clenney, 2010), the most prevailing aspects associate 
them with role congruency theory (Eagly \& Karau, 2002) according to which individuals should behave similarly to their role expectations in order to be positively evaluated.

Women are considered to exhibit more communal features than men and thus the expectation for them is to act in accordance with common female roles and behave in a friendly and warm way, while men are expected to exhibit more assertiveness, confidence and dominance (Eagly \& Carli, 2003). Negotiation is viewed as a tough procedure associated with masculine traits rather than stereotypical feminine characteristics (Kray \& Thompson, 2005; Putnam \& Kolb, 2000).

What creates a dilemma for women is the fact that although their role is not congruent with bargaining, when they violate the gender stereotype and they adopt a masculine style that could make them more effective and successful, they are socially punished and judged negatively by their counterparts (also known as backlash effect). As a result, women are pressed to exhibit an affiliative style during negotiation, perpetuating the vicious circle of their ineffectiveness (Stuhlmacher, Citera, \& Willis, 2007). This fact is in accordance with the finding that women are more hostile in virtual than face-to face negotiations, since virtual negotiations allow them to ignore labels, and reduce pressures to be relationship oriented (Stuhlmacher et al., 2007). Nevertheless, gender differences in bargaining seem to be mitigated when women hold power and high-status roles as their demands in this case are considered as legitimate (Amanatullah \& Morris, 2010).

On the other hand, numerous studies have reported that gender does not play a significant role in negotiation competitiveness (e.g. Lewicki et al., 1994; Pruitt \& Carnevale, 1993). Specifically, the meta-analysis conducted by Walters, Stuhlmacher \& Meyer (1998) showed gender differences to account for less than 1 percent of the variance in negotiators' performance. Therefore, findings that support the gender impact on negotiation should be treated with skepticism as there may be plentiful studies that have not reported their results due to the lack of statistically significant effects (Thompson, 1990).

Other individual characteristics, such as cognitive ability, also seem to offer limited insight into predicting negotiator performance (Rubin \& Brown, 1975; Pruitt \& Carnevale, 1993; Hermann \& Kogan, 1977; Thompson, 1998). Numerous investigations have documented that when individual differences variables have an impact on negotiation behavior and outcomes, slight variations in contextual features can eliminate or even reverse their effect (Walters, Stuhlmacher, \& Meyer, 1998; Thompson, 1998; Ross \& Nisbett, 1991). Individual differences in negotiation have also been criticized due to their limited practical implications, since these characteristics are beyond negotiators' control (Bazerman \& Carroll, 1987). Even if the understanding of the opponent's individual characteristics could benefit a negotiator, it is vital to remember that personality characteristics cannot be easily identified and assessed by non-experts (Morris, Larrick, 
\& Su, 1999; Morris, Leung, \& Sethi, 1995; Bazerman, 1986). Cultural differences, though, could be an exception to this because their understanding could potentially help bargainers shape the appropriate strategy (Bazerman, Curhan, Moore, \& Valley, 2000).

Culture. Negotiation research has placed great importance on bargainers' cultural differences. Culture is defined as the distinctive features of a specific group of people (Lytle et al., 1995). The norms shared by the members of a social group affect what is considered as appropriate in social interactions, and therefore in negotiation situations (Brett, 2000). Empirical research suggests that cultural characteristics, such as whether a negotiator comes from an individualistic or a collectivistic culture, affect what directs one's behavior and how the behaviors of others are interpreted (e.g. Schwartz, 1994). In individualistic cultures like the United States, individuals perceive themselves as unique, independent and detached from the social context, so they act in their own way, being unconcerned about the needs and interests of others (Markus \& Kitayama, 1991). On the other hand, in collectivistic cultures such as China, individuals are interdependent and the need for relatedness and connection with in-group members is a key condition to maintain the group solidarity (Gelfand et al., 2002).

Although substantial research has been conducted on cultural characteristics, it has yielded equivocal results regarding their impact on negotiation. Despite the fact that several studies suggest that collectivism promotes cooperative behaviors during negotiation (Brett \& Kopelman, 2004; Hemesath \& Pomponio, 1998), another line of research has concluded that people coming from collectivistic cultures are more competitive in buyer-seller negotiations (Schmidt, 1979; Adair et al., 2004), when they interact with out-group members (Triandis, 1988; Parks \& Komorita, 1998), and when a long-term relationship does not need to be established (Koch \& Koch, 2007).

\section{2) Situational or contextual features}

The social psychological research on negotiation during the 1960s and 1970s also explored the structural elements that determine the context of the bargaining situation. These variables include the type of communication between the parties (Wichman, 1970), the payoffs (Axelrod \& May, 1968), the deadlines (Pruitt \& Drews, 1969), the number of individuals representing each side (Marwell \& Schmitt, 1972), as well as the impact of the presence of third parties (Pruitt \& Johnson, 1972) and constituencies (Druckman, 1967). However, the contextual element that has received the most research attention is the negotiator's power (e.g. Marwell, Ratcliff, \& Schmitt, 1969; Kim, 1997; De Dreu, 1995; Rawwas, Vitell, \& Barnes, 1997), as it refers to an individual's ability to exert impact on others and modify the bargaining outcome (Bacharach \& Lawler, 1981; Keltner et al., 2003; Kelley \& Tribaut, 1978).

Power. Power may derive from several sources, such as a) the ability to punish people for unwanted behavior (coercive power) or b) reward them for desired behavior (reward power), c) the right to control other individuals' behavior 
based on seniority or position (legitimate power), d) and the ability to influence others due to experience, knowledge or expertise (expert power) or e) based on the admiration others feel (referent power) (French \& Raven, 1959).

In negotiation literature, though, the dominant indicator of a bargainer's power is the so-called Best Alternative To a Negotiated Agreement (BATNA; Fisher \& Uri, 1981), which is a concept derived from the social exchange theory (Thibaut \& Kelley, 1959). Social exchange theory briefly suggests that: a) social behavior involves interpersonal exchanges during which individuals get some benefits (rewards) in exchange of some resources (costs), b) people are motivated to participate in a relationship when the rewards are expected to be greater than the costs, and c) individuals are dissatisfied when they perceive the exchange as unfair or when they find out that others get more benefits for the same costs that incurred to them. So, BATNA is the alternative a person can turn to in case that it is not feasible to reach a beneficial agreement, and it is closely related to a negotiator's reservation point (RP) that describes the least acceptable point (or price) for a negotiator (Blount, Thomas-Hunt, \& Neale, 1996) or-to put it differently-it is the quantification of one's BATNA (Raiffa, 1982). BATNA is considered to be a primary source of power in negotiation since an attractive alternative makes an individual less dependent on the opponent for the outcome and therefore increases his power (Thibaut \& Gruder, 1969; Lee \& Tiedens, 2001). Power has been shown to play a significant role in negotiation as powerful bargainers seem to demand more and concede less (De Dreu, 1995), make initial offers more often (Magee et al., 2007), use more deceptive tactics (Lawler, 1992), and achieve more successful outcomes in terms of payoffs (Giebels, De Dreu, \& Van de Vliert, 2000).

Despite the fact that research on contextual factors such as power has definitely contributed to a better understanding of the bargaining process, nevertheless, from an applied perspective, these aspects of the negotiation are also beyond negotiators' control, just like the individual characteristics (Bazerman, Curhan, \& Moore, 2001). For this reason, many experts assert that the effects of such aspects of a bargaining situation depend on the way negotiators perceive, comprehend and interpret them, a view that although is consistent with social psychology's principle of construal (Ross \& Nisbett, 1991; Nisbett \& Ross, 1980) that emphasizes the significance of the personal and subjective meaning on the impact of an objective situation, it was left unexamined by situational research during these decades.

In the late 1970 s, the study of negotiation began to decline mainly due to the social cognitive movement in social psychology that focused on the cognitive aspects that influence social interactions, and left little room for interpersonal processes (Bazerman et al., 2000). Nevertheless, by the early 1980s, scholars in schools of management realized that behavioral decision research (BDR), which is an interdisciplinary field that draws on insights that emerged from cognitive revolution to describe how people judge and make decisions, could inform ne- 
gotiation theory. The rationale behind this was that if negotiators need to confront a situation and an opponent they cannot control, the only feature that is within their control is the way they make decisions. Decision researchers from several fields offered various theoretical perspectives on the common mistakes negotiators make, the ways they depart from rationality, and how their decision making can be improved; however, they did not take into consideration key social variables (Bell, Raiffa, \& Tversky, 1989) such as the bargainers' cultural characteristics.

During the $1980 s$ and $1990 s$, negotiation research focused on the cognitive aspects of bargaining, as it was strongly influenced by both behavioral decision theory and game theory (Thompson, Wang, \& Gunia, 2010). Game theory was presented by Von Neumann \& Morgenstern (1944) and was further developed by Nash $(1950,1951,1953)$ in an effort to resolve the bargaining problem that was first presented by the economist Edgeworth (1881). Game theory provides formal and standardized approaches to model bargaining and its most widely used example is the prisoner's dilemma that is a deceptively simple $2 \times 2$ matrix game where no communication exists between the participants but their choices determine both parties' outcomes.

During this period, the discipline of negotiation was divided into two components: a) normative or prescriptive models and b) descriptive models (Raiffa, 1982).

\section{1) Normative models}

Normative or prescriptive models (e.g. Von Neumann \& Morgenstern, 1944; Nash, 1950, 1951, 1953; Fisher \& Ury, 1981; Champlin \& Bognanno, 1986) describe the way impeccably rational and wise people should behave and what they should optimally do in ideal, competitive, interactive situations, and are mainly in the jurisdiction of economists and game theorists (Raiffa, 1982). These models do not adequately describe the behavior of average people in bargaining situations as it is not realistic for individuals to follow their principles (Neale \& Bazerman, 1985; Bazerman \& Neale, 1983).

In negotiation literature, the terms "normative" and "prescriptive" models are usually used interchangeably (e.g. Bazerman et al., 2000; Bazerman et al., 2001); however, several authors claim that there are slight differences between the two and therefore they should be treated distinctly. According to this view, the main difference between these two models is that normative models are assessed by the extent to which they provide rational options, or their theoretical adequacy, while prescriptive models are evaluated by their pragmatic value that is their capacity to develop "prescriptions" in order to guide people make better decisions, provided that they are not perfectly rational, mainly due to biases (Bell et al., 1989). In this article, the terms "normative" and "prescriptive" models are considered as synonymous.

\section{2) Descriptive models}

Descriptive models (e.g. Siegel \& Fouraker, 1960; Douglas, 1962; Chamberlain 
\& Kuhn, 1965; Pruitt, 1981; Pruitt, 1983a; Pruitt \& Carnevale, 1982) are empirically verified models which recognize that it is not feasible for negotiators to behave always in a perfect, game-theoretic, optimal fashion. These models have been largely the province of psychologists (Pruitt \& Rubin, 1986) as they are based on observed behaviors, and investigate the impact of personal and psychological characteristics, motivations, and cognitive processes on individual behavior and negotiation outcomes (Thompson, 1990).

One of the most influential descriptive models is the dual concern model (Pruitt, 1983b; Pruitt \& Rubin, 1986) that specifies four basic strategies available to negotiators, depending on the level of concern for own and others' outcomes (see also Figure 1):

- Problem solving or collaborating describes the endeavor for finding solutions that are approved and acceptable by both parties.

- Forcing or contending or competitiveness refers to the attempts from the individual's side to influence his counterpart in such a way so as to accept alternatives that are in favor of the former.

- Yielding or conceding concerns accepting and incorporating the other's will.

- Avoidance or inaction involves a passive stance and refers to a kind of strategy that can delay or even hinder agreement.

An additional strategy, compromising, which is based on the anticipation of a mutual give-and-take interaction, has been included in the related research (Blake \& Mouton, 1964). However, according to Pruitt (1983b), this fifth strategy is a kind of poor form of problem solving, and thus it is not necessary to be considered as a distinct one. This model supports that individuals who have a

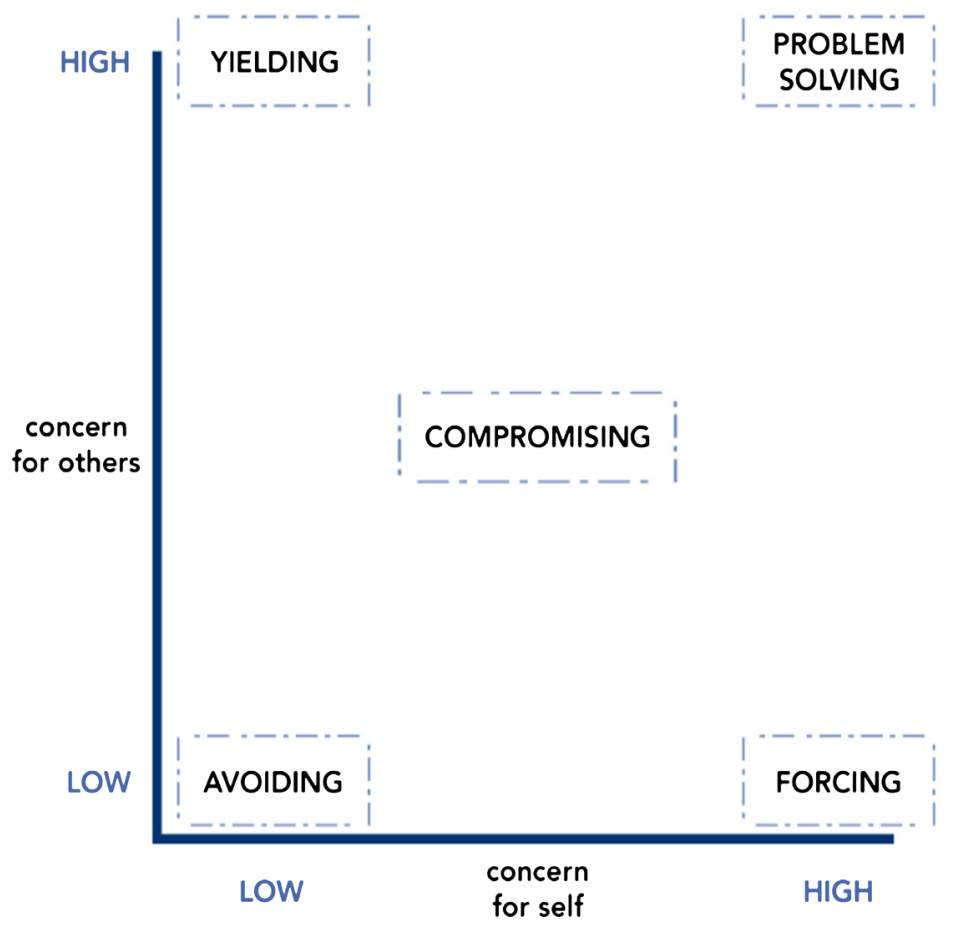

Figure 1. The dual concern model, adapted from Pruitt and Rubin (1986). 
high degree of concern for themselves and a high degree of concern for the opponent tend to reach more cooperative outcomes compared to those who are concerned only with the maximization of their own utilities, those who are not concerned with themselves or the other party or those who are concerned only with the other party.

Generally, the behavioral decision perspective had a great impact on both the scholarship and practice of negotiation but except for the fact that it left several social variables unexamined, as mentioned before, it was also criticized for not taking a broad view of the bargaining process (Greenhalgh \& Chapman, 1995; Barley, 1991). So, at the turn of the millennium, the social psychological study of negotiation started to reemerge and became the dominant research perspective of negotiation, being influenced by the behavioral decision theory but also incorporating social-psychological elements that are vital to effective negotiations and were previously ignored by cognitive investigators.

In summary, negotiation research has undergone several phases during the past decades. Throughout the 1960s and 1970s, negotiation was an active research topic within social psychology. The study of both individual differences, with an emphasis on gender and culture, and situational characteristics such as the negotiator's power led to a better understanding of the factors that affect this interpersonal activity. In the late 1970s, the cognitive revolution in psychology moved negotiation research towards a cognitive direction. During the 1980s and 1990s, negotiation research was heavily influenced by game theory and behavioral decision-making perspective, but left unexamined significant social components of the negotiation process. For this reason, since the late 1990s, there have been extensive efforts to reintroduce the social factors in the study of negotiation and incorporate them within the behavioral decision perspective. Emotions and social relationships are among the key social-psychological factors the scholarship and practice of negotiation seek to explore during these decades (Bazerman, Curhan, \& Moore, 2001).

\section{The Role of Emotions in Negotiation}

The difficulty in defining emotion is conspicuous from what Fehr \& Russell (1984: p. 464) noted: "Everyone knows what an emotion is, until asked to give a definition. Then, it seems, no one knows". Emotions can be positive or negative. The former are uplifting while the latter are distressing (Fisher \& Shapiro, 2005). At this point it is helpful to highlight the differences between emotion, mood, and affect. Emotion refers to the physiological arousal resulting in response to a specific stimulus, it is explicitly other-directed and has a relatively short duration (Parrott, 2001; Oatley \& Jenkins, 1996) while mood describes a diffuse positive or negative feeling (Forgas, 1998) and affect is a construct including both emotion and mood (Gino \& Shea, 2012). Although these terms are often used interchangeably, it is worth mentioning that they are discrete concepts that are equally significant in the study of negotiation. 
Emotion is inherent in negotiation as it is an integral and indispensable part of human nature and experience (Fromm, 2007). The role of emotion in bargaining is complex and multifaceted. Conflict and negotiation can cause intense emotions that may affect the behavior of all involved parties as well as the final negotiation outcome (Barry, Fulmer, \& Van Kleef, 2004). Evidence from neuroscience has shown that emotions are vital in decision making and their absence can lead to similarly unfavorable consequences as the ones occurring from the presence of negative emotions (Damasio, 1999). On the other hand, suppressing emotions can also bring about quite detrimental effects as it results to reduced cognitive ability. As Fisher \& Shapiro (2005) assert, emotions are unavoidable during negotiations, it is not feasible for people to get rid of them, it is meaningless to try to ignore them and it is too complicated to deal directly with them. So, the best solution is to stimulate and enlist positive emotions into negotiation as well as to replace negative emotions with positive ones; however, in any case, negotiators should first know what is going on inside them (Goleman, 1998).

The emotions individuals experience and express during negotiation can shape the procedure and determine the outcome by affecting their cognition, decisions, strategies and actions (Lanzetta, 1989; Frijda, 1986). According to Fisher \& Shapiro (2005), emotions can be both obstacles and great assets in negotiations. They can be impediments since they have the power to divert attention from essential issues, ruin relationships or exploit oneself while they can be considered as assets since they can help individuals to achieve their goals, satisfy their interests and improve relationships.

Intrapersonal and interpersonal effects of emotions. Bargainers' emotions not only affect themselves but also their opponents (Van Kleef, De Dreu, \& Manstead, 2006). A significant distinction that should be pointed out is between intrapersonal and interpersonal effects of emotions in negotiation (Morris \& Keltner, 2000; Van Kleef, De Dreu, \& Manstead, 2004). Intrapersonal effects (or affect-cognitive perspective) focus on the impact of particular emotions and inner experiences on an individual's own behavior while interpersonal effects (or social-functional perspective) describe how one person's emotions can affect his counterpart's behavior (Gino \& Shea, 2012; Van Kleef, 2008).

Despite the fact that prior negotiation research had mostly emphasized the affect-cognitive perspective, the last few years more and more researchers have turned their attention to understanding the interpersonal effects of emotions in negotiation (Barry, Fulmer, \& Van Kleef, 2004; Morris \& Keltner, 2000; Jehn \& Mannix, 2001). From a social-functional perspective, emotions reveal useful information about individuals' motives, social intentions, behavioral orientation, interests and feelings and thus they have the power to stimulate others' behavior (Ekman, 1993; Keltner \& Haidt, 1999; Cacioppo \& Gardner, 1999).

Positive emotions. Positive emotions have drawn special attention the past few years, probably due to the development of positive psychology. The mission of this new domain of psychology is to study positive emotions, positive charac- 
ter traits, and positive institutions and to contribute to the understanding of the factors that lead to flourishing (Seligman \& Csikszentmihalyi, 2000). Positive emotions both signal and produce flourishing and when cultivated they contribute to psychological growth and improved well-being in the long term (Fredrickson, 2001), while they also foster cognitive expansion as they trigger the release of dopamine which improves cognitive ability and encourages creative thinking (Shapiro, 2004). In addition, according to the broaden-and-build theory (Fredrickson, 1998, 2001), positive emotions have the ability to broaden individuals' momentary thought-action repertoire and build their enduring physical, intellectual and social resources, while at the same time they eliminate the unfavorable consequences caused by negative emotions, acting as an antidote.

Positive emotions have been associated with the use of cooperative negotiation strategies (Pietroni et al., 2008; Rhoades, Arnold, \& Jay, 2001; Carnevale, 2008; Carnevale \& Isen, 1986; Hollingshead \& Carnevale, 1990; Baron, 1990; Barsade, 2002; Barry \& Oliver, 1996; Kramer, Newton, \& Pommerenke, 1993; Baron et al., 1990; Forgas, 1998). In addition, they have been found to facilitate conflict resolution (Lyubomirsky et al., 2005), enhance creative problem solving abilities (Carnevale \& Isen, 1986; Isen, Daubman, \& Nowicki, 1987), facilitate conciliatoriness (Van Kleef, 2008) and concession making (Forgas, 1998; Baron, 1990), increase joint gains and distributive success (Carnevale \& Isen, 1986; Allred et al., 1997; Forgas, 1998), help bargainers avoid hostility (Isen \& Baron, 1991), and discourage the use of deception and contentious tactics (Olekalns \& Smith, 2009; Carnevale \& Isen, 1986) such as information misrepresenting, use of false statements, bluffing and lying (Bazerman et al., 2000; Boles, Croson, \& Murnighan, 2000; O'Connor \& Carnevale, 1997).

Furthermore, it has been shown that negotiators whose opponents express happiness tend to feel happy, satisfied and willing to repeat involvement in a bargaining situation with the same person in the future (Van Kleef, De Dreu, \& Manstead, 2004). Moreover, they accept offers with greater ease and willingness (Mussel, Göritz, \& Hewig, 2013), and tend to concede more (Pietroni et al., 2009). There is strong evidence that positive affect influences social judgment and impacts on evaluations in a positive way (Isen et al., 1978; Veitch \& Griffitt, 1976), increases the accessibility to memory's positive material (Isen et al., 1978), decreases hostility and belligerence (Carnevale \& Pegnetter, 1985), encourages innovative solutions to problems (Isen et al., 1985), make individuals feel that they are more effective than their opponents (Kramer et al., 1993), and help bargainers to obtain integrative outcomes (Carnevale \& Isen, 1986).

Positive relations: The case of trust. In recent years, researchers have turned their attention on the ways that interpersonal relationships can have an impact on bargaining situations (e.g. Jehn \& Shah, 1997; Jehn \& Mannix, 2001). One topic in this area that is widely acknowledged to affect negotiation behavior and outcomes is trust which can be defined as a person's willingness to be open to risk and vulnerable to another individual or the judgment that an individual 
does not have the intention to neither deceive nor harm the trusting person (Mayer, Davis, \& Schoorman, 1995; Mayer \& Davis, 1999; Rousseau et al., 1998).

Trust makes negotiators consider information their counterparts share as sincere and accurate (Parks et al., 1996), increases individuals' tendency to compromise and decreases the inclination for adopting competitive strategies (Cronin \& Weingart, 2005), and generally leads to more integrative negotiation outcomes (Butler, 1995; Weingart et al., 1993; Pruitt \& Kimmel, 1977). Furthermore, high levels of trust lead to a greater desire to negotiate again with the same counterpart (Naquin \& Paulson, 2003) as the perception of a relationship as close, strong and cohesive enhances the willingness to stay in this relationship (Lawler \& Yoon, 1996).

Despite the significance of trust, negotiators often violate it (Elangovan \& Shapiro, 1998) by making use of deceptive tactics such as lies, bluffs, false statements, threats and disclaimers, in order to get the desired outcomes and maximize their profits (Thompson, Wang, \& Gunia, 2010). When this is the case, trust is extremely difficult to be restored in the future (Glick \& Croson, 2001). More specifically, according to Schweitzer et al. (2006), violated trust can never be totally restored, not even after the trust breaker has demonstrated regret and has performed numerous trustworthy actions. On the other hand, Kim et al. (2004) support that a trust breaker can win his counterpart's trust when its violation concerns an issue of competence but its recovery is not feasible when its violation relates to a matter of integrity.

Negative emotions. In contrast to positive emotions, negative emotions have been found to impede interest-based negotiation in general as they encourage dysfunctional and competitive behaviors and strategies (Liu, 2009; Forgas, 1998; Barry \& Oliver, 1996; Baron, 1990), decrease initial offers (Brooks \& Schweitzer, 2011; Baron et al., 1990) and joint gains (Allred et al., 1997), contribute to the rejection of ultimatum offers (Pillutla \& Murnighan, 1996; Espinoza, Fedokhinin, \& Srivastava, 2006), make negotiators more self-centered and less concerned about the other party (Loewenstein et al., 1989), enhance the reluctance for concessions (Van Kleef, 2008), increase the possibilities for impasse (Griessmair, 2017), and reduce the desire for future negotiation (Allred et al., 1997).

When individuals confront a counterpart who expresses negative emotions, they feel unsatisfied and reluctant to get involved in a negotiation with the same person in the future (Van Kleef, De Dreu, \& Manstead, 2004). To date, although research on emotions in negotiation is relatively sparse, several studies have been conducted on the emotion of anger (e.g. Allred et al., 1997; Van Dijk et al., 2008; Van Kleef et al., 2004; Sinaceur \& Tiedens, 2006). Anger has been found to be the most prominent and pervasive emotion that can arise in dispute and negotiation (Allred, 1999) as it is closely associated with fairness judgments (Averill, 1982) that play a crucial role in deal making and conflict resolution (Daly, 1991). Anger carries a high potential risk for disrupting bargaining. It may lead to deception and this can be explained by the fact that when a negotiator expresses 
anger throughout the negotiation, the counterpart may feel offended and has the need to retaliate or even deceive (Allred, 1999). Research findings have shown that individuals may react to their opponents' expressed anger either with a reciprocal response (Hatfield, Cacioppo, \& Rapson, 1992) or with a complementary one (Butt, Choi, \& Jaeger, 2005).

From a cognitive perspective, anger is perceived by the opponent as lack of fairness (Van Doorn, Van Kleef, \& Van der Pligt, 2015), fosters the expectation of a difficult and competitive negotiation, and leads to absence of interest and withdrawal (Knapp \& Miller, 1985). To put it all in a nutshell, it seems that feeling and expressing of anger can be effective in distributive negotiations but it is likely to be detrimental in cases where an integrative potential exists and also in situations where future relationship between bargainers is significant (Liu, 2009).

Another negative emotion that has received some attention is that of disappointment that-as opposed to regret-has been found to lead to less generous offers (Martinez, Zeelenberg, \& Rijsman, 2011). Interestingly, individuals experience more satisfaction when their opponents are disappointed than when they are happy (Thompson, Valley, \& Kramer, 1995), and tend to concede more (Van Kleef \& Van Lange, 2008). Disappointment can influence negotiation by encouraging cooperation (Ketelaar \& Au, 2003; Wietzker et al., 2012) and shaping the opponent's offers (Nelissen et al., 2011; Lelieveld et al., 2011) due to the fact that it stimulates feelings of guilt in the other party. Bargainers who negotiate with a guilty or regretful opponent assume that the other party claimed too much and makes them increase their demands (Van Kleef, De Dreu, \& Manstead, 2006).

Significant dilemmas. There is evidence that anger may have positive effects during negotiation (Sinaceur \& Tiedens, 2006) as an individual who negotiates with an angry counterpart is more likely to demonstrate willingness to make concessions compared to an individual negotiating with a happy opponent. However, according to Harinck and Van Kleef (2012), the benefits of anger are limited to conflicts about interests (disagreements about the distribution of resources) while when conflicts concern values (disagreements about personal beliefs and norms) anger expression may trigger retaliation. The positive effects of anger seem to occur in computer-mediating settings, where time pressure is high, the beneficial effect depends on the strength of the counterpart's alternatives (Sinaceur \& Tiedens, 2006; Van Dijk et al., 2008), or when the negotiator facing the angry opponent is of lower power (Van Kleef, De Dreu, \& Manstead, 2004).

As discussed, power and status play a significant role in negotiations and have a great impact on the felt and expressed emotions. Generally, anger seems to benefit high-power negotiators extract larger concessions from their counterparts due to the fact that they elicit fear in them, while those possessing low power make more concessions to their opponents expressing anger and claim 
less value from them (Butt \& Choi, 2009; Van Kleef \& Côté, 2007; Lelieveld et al., 2012; Wang, Northcraft, \& Van Kleef, 2012). However, in such cases, low power negotiators may reciprocate by being engaged in any forms of covert retaliation (Wang, Northcraft, \& Van Kleef, 2012).

Negotiators with high power, when they are angry, feel energized and increase their demands while in case that they need to face an angry opponent they claim more value, but only when they assess the anger as unjustified (Overbeck et al., 2010; Van Kleef \& Côté, 2007). Nonetheless, when negotiators with power and high-status express happiness, their perceived dominance decreases leading to lower demands and gains while this finding is opposite for low-power and status bargainers whose expressed happiness can result to increased outcomes (Kurtzberg, Naquin, \& Belkin, 2005). As far as joint outcomes are concerned, they are much greater when positive affect is communicated from a high-power than a low-power negotiator (Anderson \& Thompson, 2004).

To summarize, although positive emotions seem to lead to better and more integrative negotiation outcomes, there are also findings showing that negative emotions such as anger can benefit negotiators under certain circumstances. The study of emotions in bargaining situations is still at an embryonic stage and these inconsistencies reveal that further research is needed and several factors should be taken into consideration before we decide which emotions should be triggered under which conditions in order to achieve the desired negotiation outcomes. Therefore, negotiation needs to be examined as a complex process and a multilevel phenomenon where although emotions play a significant role, the types of emotions that are most appropriate in certain situations may depend upon numerous variables that should be identified.

\section{Conclusion}

Negotiation literature is one of the most complex ones mainly due to the fact that negotiation research has been profoundly influenced by numerous disciplines. Countless theories have been expressed and plentiful models have been formulated in an attempt to enhance negotiators' performance. Over the past few years, the psychological study of negotiation has witnessed an amazing shift as several researchers have challenged the impact of cognition in bargaining by studying how emotions can affect and predict negotiated outcomes (Barry \& Oliver, 1996; Kumar, 1997; Baron, 1990; Barsade, 2002; Thompson, Nadler, \& Kim, 1999; Forgas, 1998).

Evidence has shown that positive emotions benefit bargainers in several ways while negative or even neutral feelings usually lead to severe negative consequences. Nevertheless, the present study reveals several inconsistencies among findings that can be explained by the complexity of the topic, the plethora of factors to be taken under consideration as well as the fact that the study of emotions in negotiation is still in its incipient stage and further research is needed.

The interest on emotions in negotiation, which has increased during the past 
few years, is probably related to the emergence of positive psychology as a new field of psychology at the same period. The discipline of positive psychology, which is the scientific study of positive emotions, has contributed to the understanding of how positivity can lead to enhanced results in several aspects of life. Therefore, we can hypothesize that its principles may successfully apply to bargaining and that the broadening and building effects of positive emotions, as described by Fredrickson $(1998,2001)$ and Seligman (2002), can decisively and positively affect negotiation behaviors and processes leading to more advantageous outcomes for all parties involved. Nevertheless, this hypothesis has not been confirmed and thus further research is needed in order to find out whether and how positive psychology can contribute to the better understanding of negotiation.

\section{Conflicts of Interest}

The authors declare no conflicts of interest regarding the publication of this paper.

\section{References}

Adair, W., Brett, J., Lempereur, A., Okumura, T., Shikhirev, P., Tinsley, C., \& Lytle, A. (2004). Culture and Negotiation Strategy. Negotiation Journal, 20, 87-111. https://doi.org/10.1111/j.1571-9979.2004.00008.x

Adler, N. J., Graham, J. L., \& Gehrke, T. S. (1987). Business Negotiations in Canada, Mexico, and the United States. Journal of Business Research, 15, 411-429. https://doi.org/10.1016/0148-2963(87)90010-5

Allport, F. (1955). Theories of Perception and the Concept of Structure. New York: Wiley.

Allred, K. G. (1999). Anger and Retaliation: Toward an Understanding of Impassioned Conflict in Organizations. In R. J. Bies, R. J. Lewicki, \& B. H. Sheppard (Eds.), Research on Negotiation in Organizations (Vol. 7, pp. 27-58). Stamford, CT: JAI Press.

Allred, K. G., Mallozzi, J. S., Matsui, F., \& Raia, C. P. (1997). The Influence of Anger and Compassion on Negotiation Performance. Organizational Behavior and Human Decision Processes, 70, 175-187. https://doi.org/10.1006/obhd.1997.2705

Amanatullah, E. T., \& Morris, M. W. (2010). Negotiating Gender Roles: Gender Differences in Assertive Negotiating are Mediated by Women's Fear of Backlash and Attenuated When Negotiating on Behalf of Others. Journal of Personality and Social Psychology, 98, 256-267. https://doi.org/10.1037/a0017094

Anderson, C., \& Thompson, L. L. (2004). Affect from the Top down: How Powerful Individuals' Positive Affect Shapes Negotiations. Organizational Behavior and Human Decision Processes, 95, 125-139. https://doi.org/10.1016/j.obhdp.2004.05.002

Averill, J. R. (1982). Anger and Aggression. New York: Springer. https://doi.org/10.1007/978-1-4612-5743-1

Axelrod, S., \& May, J. G. (1968). Effect of Increased Reward on the Two-Person NonZero-Sum Game. Psychological Reports, 23, 675-678. https://doi.org/10.2466/pr0.1968.23.2.675

Babcock, L., \& Laschever, S. (2003). Women Don't Ask: Negotiation and the Gender Divide. Princeton, NJ: Princeton University Press. https://doi.org/10.1515/9781400825691 
Babcock, L., Gelfand, M., Small, D., \& Stayhn, H. (2006). Gender Differences in the Propensity to Initiate Negotiations. In D. De Cremer, M. Zeelenberg, \& J. K. Murnighan (Eds.), Social Psychology and Economics (pp. 239-262). Mahwah, NJ: Erlbaum.

Bacharach, S., \& Lawler, E. (1981). Bargaining: Power, Tactics, and Outcomes. San Francisco, CA: Jossey-Bass.

Barley, S. R. (1991). Contextualizing Conflict: Notes on the Anthropology of Dispute and Negotiation. In M. H. Bazerman, R. Lewicki, \& B. Sheppard (Eds.), Handbook of Research in Negotiation (Vol. 3). Greenwich, CT: JAI Press.

Baron, R. A. (1990). Environmentally Induced Positive Affect: Its Impact on Self-Efficacy, Task Performance, Negotiation, and Conflict. Journal of Applied Social Psychology, 20, 368-384. https://doi.org/10.1111/j.1559-1816.1990.tb00417.x

Baron, R. A., Fortin, S. P., Frei, R. L., Hauver, L. A., \& M. L. Shack (1990). Reducing Organizational Conflict: The Role of Socially-Induced Positive Affect. International Journal of Conflict Management, 1, 133-152. https://doi.org/10.1108/eb022677

Barry, B. (1999). The Tactical Use of Emotion in Negotiation. In R. J. Bies, R. J. Lewicki, \& B. H. Sheppard (Eds.), Research on Negotiation in Organizations (Vol. 7, pp. 93 121). Greenwich, CT: JAI.

Barry, B., \& Friedman, R. A. (1998). Bargainer Characteristics Distributive and Integrative Negotiation. Journal of Personality and Social Psychology, 74, 345-359. https://doi.org/10.1037/0022-3514.74.2.345

Barry, B., \& Oliver, R. L. (1996). Affect in Dyadic Negotiation: A Model and Propositions. Organizational Behavior and Human Decision Processes, 67, 127-143. https://doi.org/10.1006/obhd.1996.0069

Barry, B., Fulmer, I. S., \& Van Kleef, G. (2004). I Laughed, I Cried, I Settled: The Role of Emotion in Negotiation. In M. J. Gelfand, \& J. M. Brett (Eds.), The Handbook of Negotiation and Culture: Theoretical Advances and Cross-Cultural Perspectives (pp. 71-94). Palo Alto, CA: Stanford University Press.

Barsade, S. G. (2002). The Ripple Effect: Emotional Contagion and Its Influence on Group Behavior. Administrative Science Quarterly, 47, 644-675. https://doi.org/10.2307/3094912

Bazerman, M. (1986). Judgment in Managerial Decision Making. New York: Wiley.

Bazerman, M. H., \& Carroll, J. S. (1987). Negotiator Cognition. Research in Organizational Behavior, 9, 247-288.

Bazerman, M. H., \& Neale, M. A. (1983). Heuristics in Negotiation: Limitations to Effective Dispute Resolution. In M. H. Bazerman, \& R. J. Lewicki (Eds.), Negotiating in Organizations (pp. 51-67). Beverly Hills, CA: Sage.

Bazerman, M. H., Curhan, J. R., \& Moore, D. A. (2001). The Death and Rebirth of the Social Psychology of Negotiation. In G. J. O. Fletcher, \& M. S. Clark (Eds.), Blackwell Handbook of Social Psychology: Interpersonal Processes (pp. 196-228). Oxford, England: Blackwell Publishers. https://doi.org/10.1002/9780470998557.ch8

Bazerman, M. H., Curhan, J. R., Moore, D. A., \& Valley, K. L. (2000). Negotiation. Annual Review of Psychology, 51, 279-314.

https://doi.org/10.1146/annurev.psych.51.1.279

Bell, D. E., Raiffa, H., \& Tversky, A. (1989). Decision Making: Descriptive, Normative and Prescriptive Interactions. Cambridge, England: Cambridge University Press. https://doi.org/10.1017/CBO9780511598951

Bernard, J. (1957). The Sociological Study of Social Conflict. In International Sociological Association, The Nature of Conflict. Paris: UNESCO. 
Blake, R. R., \& Mouton, J. S. (1964). The Managerial Grid. Houston, TX: Gulf Publications.

Blount, S., Thomas-Hunt, M. C., \& Neale, M. A. (1996). The Price Is Right-Or Is It? A Reference Point Model of Two-Party Price Negotiations. Organizational Behavior and Human Decision Processes, 68, 1-12. https://doi.org/10.1006/obhd.1996.0085

Boles, T., Croson, R., \& Murnighan, J. (2000). Deception and Retribution in Repeated Ultimatum Bargaining. Organizational Behavior and Human Decision Processes, 83, 235 259. https://doi.org/10.1006/obhd.2000.2908

Bowles, H. R., Babcock, L., \& Lai, L. (2007). Social Incentives for Gender Differences in the Propensity to Initiate Negotiations: Sometimes It Does Hurt to Ask. Organizational Behavior and Human Decision Processes, 103, 84-103. https://doi.org/10.1016/j.obhdp.2006.09.001

Bowles, H. R., Babcock, L., \& McGinn, K. L. (2005). Constraints and Triggers: Situational Mechanics of Gender in Negotiation. Journal of Personality and Social Psychology, 89, 951-965. https://doi.org/10.1037/0022-3514.89.6.951

Brett, J. M. (2000). Culture and Negotiation. International Journal of Psychology, 35, 97-104. https://doi.org/10.1080/002075900399385

Brett, J. M., \& Kopelman, S. (2004). Cross-Cultural Perspectives on Cooperation in Social Dilemmas. In M. J. Gelfand, \& J. M. Brett (Eds.), Handbook of Negotiation and Culture (pp. 395-411). Stanford, CA: Stanford University Press.

Brooks, A. W., \& Schweitzer, M. (2011). Can Nervous Nelly Negotiate? How Anxiety Causes Negotiators to Make Low First Offers, Exit Early, and Earn Less Profit. Organizational Behavior and Human Decision Processes, 115, 43-54. https://doi.org/10.1016/j.obhdp.2011.01.008

Butler, J. K. (1995). Behaviors, Trust, and Goal Achievement in a Win-Win Negotiating Role Play. Group and Organization Management, 20, 486-501. https://doi.org/10.1177/1059601195204006

Butt, A. N., \& Choi, J. N. (2009). Does Power Matter? Negotiator Status as a Moderator of the Relationship between Negotiator Emotion and Behavior. International Journal of Conflict Management, 21, 124-146. https://doi.org/10.1108/10444061011037378

Butt, A. N., Choi, J. N., \& Jaeger, M. (2005). The Effects of Self-Emotion, Counterpart Emotion, and Counterpart Behavior on Negotiator Behavior: A Comparison of Individual-Level and Dyad-Level Dynamics. Journal of Organizational Behavior, 26, 681-704. https://doi.org/10.1002/job.328

Cacioppo, J. T., \& Gardner, W. L. (1999). Emotion. Annual Review of Psychology, 50, 191-214. https://doi.org/10.1146/annurev.psych.50.1.191

Callahan, S. (1988). The Role of Emotion in Ethical Decisionmaking. The Hastings Center Report, 18, 9-14. https://doi.org/10.2307/3562196

Carnevale, P. J. (2008). Positive Affect and Decision Frame in Negotiation. Group Decision and Negotiation, 17, 51-63. https://doi.org/10.1007/s10726-007-9090-X

Carnevale, P. J. D., \& Pegnetter, R. (1985). The Selection of Mediation Tactics in Public-Sector Disputes: A Contingency Analysis. Journal of Social Issues, 41, 65-81. https://doi.org/10.1111/j.1540-4560.1985.tb00855.x

Carnevale, P. J., \& Isen, A. M. (1986). The Influence of Positive Affect and Visual Access on the Discovery of Integrative Solutions in Bilateral Negotiation. Organizational Behavior and Human Decision Processes, 37, 1-13. https://doi.org/10.1016/0749-5978(86)90041-5

Chamberlain, N. W., \& Kuhn, J. W. (1965). Collective Bargaining (2nd ed.). New York: 
McGraw-Hill.

Champlin, F. C., \& Bognanno, M. F. (1986). A Model of Arbitration and the Incentive to Bargain. In D. B. Lipsky, \& D. Lewin (Eds.), Advances in Industrial and Labor Relations (Vol. 3, pp. 153-190). Greenwich, CT: JAI.

Chertkoff, J. M., \& Esser, J. K. (1976). A Review of Experiments in Explicit Bargaining. Journal of Experimental Social Psychology, 12, 464-486. https://doi.org/10.1016/0022-1031(76)90078-0

Cronin, M. A., \& Weingart, L. R. (2005). The Differential Roles of Respect and Trust on Negotiation. IACM 18th Annual Conference. https://doi.org/10.2139/ssrn.726183

Curhan, J. R., Elfenbein, H. A., \& Eisenkraft, N. (2010). The Objective Value of Subjective Value: A Multi-Round Negotiation Study. Journal of Applied Social Psychology, 40, 690-709. https://doi.org/10.1111/j.1559-1816.2010.00593.x

Curhan, J. R., Elfenbein, H. A., \& Xu, H. (2006). What Do People Value When They Negotiate? Mapping the Domain of Subjective Value in Negotiation. Journal of Personality and Social Psychology, 91, 493-512. https://doi.org/10.1037/0022-3514.91.3.493

Dalton, D. R., \& Todor, W. D. (1985). Composition of Dyads as a Factor in the Outcome of Workplace Justice. Academy of Management Journal, 28, 704-712.

Dalton, D. R., Todor, W. D., \& Owen, C. L. (1987). Sex Effects in Workplace Justice Outcomes: A Field Assessment. Journal of Applied Psychology, 72, 156-159.

https://doi.org/10.1037/0021-9010.72.1.156

Daly, J. P. (1991). The Effects of Anger on Negotiations over Mergers and Acquisitions. Negotiation Journal, 7, 31-39. https://doi.org/10.1111/j.1571-9979.1991.tb00600.x

Damasio, A. (1999). The Feeling of What Happens: Body and Emotion in the Making of Consciousness. New York: Harcourt Brace.

Davidson, M. N., \& Greenhalgh, L. (1999). The Role of Emotion in Negotiation: The Impact of Anger and Race. Research on Negotiation in Organizations, 7, 3-26.

De Dreu, C. K. W. (1995). Coercive Power and Concession Making in Bilateral Negotiation. Journal of Conflict Resolution, 39, 646-670.

https://doi.org/10.1177/0022002795039004003

Deal, J. J. (2000). Gender Differences in the Intentional Use of Information in Competitive Negotiations. Small Group Research, 31, 702-723. https://doi.org/10.1177/104649640003100604

Deutsch, M. (1973). The Resolution of Conflict. New Haven, CT: Yale University Press.

Douglas, A. (1962). Industrial Peacemaking. New York: Columbia University Press. https://doi.org/10.7312/doug91576

Druckman, D. (1967). Dogmatism, Prenegotiation Experience, and Simulated Group Representations Determinants of Dyadic Behavior in a Bargaining Situation. Journal of Personality and Social Psychology, 6, 279-290. https://doi.org/10.1037/h0024735

Druckman, D. (1968). Ethnocentrism in the Inter-Nation Simulation. Journal of Conflict Resolution, 12, 45-68. https://doi.org/10.1177/002200276801200104

Druckman, D. (1977). Negotiations: Social-Psychological Perspectives. Beverly Hills, CA: Sage.

Druckman, D., \& Broome, B. J. (1991). Value Differences and Conflict Resolution: Familiarity or Liking? Journal of Conflict Resolution, 35, 571-593.

https://doi.org/10.1177/0022002791035004001

Eagly, A. H., \& Carli, L. L. (2003). The Female Leadership Advantage: An Evaluation of the Evidence. The Leadership Quarterly, 14, 807-834. 
https://doi.org/10.1016/j.leaqua.2003.09.004

Eagly, A. H., \& Karau, S. J. (2002). Role Congruity Theory of Prejudice toward Female Leaders. Psychological Review, 109, 573-598. https://doi.org/10.1037/0033-295X.109.3.573

Edgeworth, F. Y. (1881). Mathematical Psychics. London: Kegan Paul.

Ekman, P. (1993). Facial Expression and Emotion. American Psychologist, 48, 384-392. https://doi.org/10.1037/0003-066X.48.4.384

Elangovan, A. R., \& Shapiro, D. I. (1998). Betrayal of Trust in Organizations. Academy of Management Review, 23, 547-566. https://doi.org/10.5465/amr.1998.926626

Espinoza, F., Fedokhinin, A., \& Srivastava, J. (2006). Anger in Ultimatum Bargaining: Emotion Outcomes Lead to Irrational Decisions. Advances in Consumer Research, 33, 264-265.

Fehr, B., \& Russell, J. A. (1984). Concept of Emotion Viewed from a Prototype Perspective. Journal of Experimental Psychology: General, 113, 464-486. https://doi.org/10.1037/0096-3445.113.3.464

Fisher, R., \& Shapiro, D. (2005). Beyond Reason: Using Emotions as You Negotiate. New York: Viking Press.

Fisher, R., \& Ury, W. R. (1981). Getting to Yes. Boston, MA: Houghton-Mifflin.

Forgas, J. P. (1998). On Being Happy and Mistaken: Mood Effects on the Fundamental Attribution Error. Journal of Personality \& Social Psychology, 75, 318-331. https://doi.org/10.1037/0022-3514.75.2.318

Fredrickson, B. L. (1998). Cultivated Emotions: Parental Socialization of Positive Emotions and Self-Conscious Emotions. Psychological Inquiry, 9, 279-281. https://doi.org/10.1207/s15327965pli0904_4

Fredrickson, B. L. (2001). The Role of Positive Emotions in Positive Psychology: The Broaden-and-Build Theory of Positive Emotions. American Psychologist, 56, 218-226. https://doi.org/10.1037/0003-066X.56.3.218

French, J. R. P., \& Raven, B. (1959). The Bases of Social Power. In D. Cartwright (Ed.), Studies in Social Power (pp. 150-167). Ann Arbor, MI: Institute for Social Research.

Frijda, N. H. (1986). The Emotions. Cambridge, England: Cambridge University Press.

Gelfand, M. J., Higgins, M., Nishii, L. H., Raver, J. L., Dominguez, A., Murakami, F., Yamaguchi, S. A., \& Toyama, M. (2002). Culture and Egocentric Perceptions of Fairness in Conflict and Negotiation. Journal of Applied Psychology, 87, 833-845. https://doi.org/10.1037/0021-9010.87.5.833

Gerhart, B., \& Rynes, S. (1991). Determinants and Consequences of Salary Negotiations by Male and Female MBA Graduates. Journal of Applied Psychology, 76, 256-262. https://doi.org/10.1037/0021-9010.76.2.256

Ghauri, P., \& Usunier, J. (2003). International Business Negotiations (2nd ed.). Oxford: Pergamon.

Gibson, D. E., \& Schroeder, S. (2002). Grinning, Frowning, and Emotionless: Agent Perceptions of Power and Their Effect on Felt and Displayed Emotions in Influence Attempts. In N. Ashkanasy, C. Hartel, \& W. Zerbe (Eds.), Managing Emotions in the Workplace (pp. 184-211). Armonk, NY: M. E. Sharpe.

Giebels, E., De Dreu, C. K. W., \& Van de Vliert, E. (2000). Interdependence in Negotiation: Effects of Exit Options and Social Motive on Distributive and Integrative Negotiation. European Journal of Social Psychology, 30, 255-272.

https://doi.org/10.1002/(SICI)1099-0992(200003/04)30:2<255::AID-EJSP991>3.0.CO;2-7 
Gilkey, R. W., \& Greenhalgh, L. (1984). Developing Effective Negotiation Approaches among Professional Women in Organizations. Paper presented at the Conference on Women and Organizations, Simmons College, Boston.

Gino, F., \& Shea, C. (2012). Deception in Negotiations: The Role of Emotions. In R. Croson, \& G. Bolton (Eds.), Handbook of Conflict Resolution. New York: Oxford University Press. https://doi.org/10.1093/oxfordhb/9780199730858.013.0005

Glick, S., \& Croson, R. (2001). Reputation in Negotiations. In S. Hoch, \& H. Kunreuther (Eds.), Wharton on Making Decisions (pp. 177-186). New York: Wiley.

Goleman, D. (1998). Working with Emotional Intelligence. New York: Bantam.

Greenhalgh, L., \& Chapman, D. I. (1995). Joint Decision Making: The Inseparability of Relationships and Negotiation. In R. Kramerand, \& D. Messick (Eds.), Negotiation as a Social Process: New Trends in Theory and Research (pp. 166-185). Thousand Oaks, CA: Sage. https://doi.org/10.4135/9781483345369.n8

Griessmair, M. (2017). Ups and Downs: Emotional Dynamics in Negotiations and Their Effects on (In)Equity. Group Decision and Negotiation, 26, 1061-1090.

https://doi.org/10.1007/s10726-017-9541-y

Güth, W., Schmittberger, R., \& Schwarze, B. (1982). An Experimental Analysis of Ultimatum Bargaining. Journal of Economic Behavior and Organization, 3, 367-388. https://doi.org/10.1016/0167-2681(82)90011-7

Harinck, F., \& Van Kleef, G. A. (2012). Be Hard on the Interests and Soft on the Values: Conflict Issue Moderates the Effects of Anger in Negotiations. British Journal of Social Psychology, 51, 741-752. https://doi.org/10.1111/j.2044-8309.2011.02089.x

Hatfield, E., Cacioppo, J. T., \& Rapson, R. L. (1992). Primitive Emotional Contagion. In M. S. Clark (Ed.), Emotion and Social Behavior: Review of Personality and Social Psychology (pp. 151-177). Newbury Park, CA: Sage. https://doi.org/10.1017/CBO9781139174138

Hemesath, M., \& Pomponio, X. (1998). Cooperation and Culture: Students from China and the United States in a Prisoner's Dilemma. Cross-Cultural Research, 32, 171-184. https://doi.org/10.1177/106939719803200203

Hermann, M. G., \& Kogan, N. (1977). Effects of Negotiators' Personalities on Negotiating Behavior. In D. Druckman (Ed.), Negotiation: Social-Psychological Perspectives (pp. 247-274). Beverly Hills, CA: Sage.

Hollingshead, A. B., \& Carnevale, P. (1990). Positive Affect and Decision Frame in Integrative Bargaining: A Reversal of the Frame Effect. Academy of Management Best Paper Proceedings, 1990, 385-389. https://doi.org/10.5465/ambpp.1990.4980390

Isen, A. M., \& Baron, R. A. (1991). Positive Affect as a Factor in Organizational Behavior. Research in Organizational Behavior, 13, 1-53.

Isen, A. M., Johnson, M. M. S., Mertz, E., \& Robinson, G. F. (1985). The Influence of Positive Affect on the Unusualness of Word Associations. Journal of Personality and Social Psychology, 48, 1413-1426. https://doi.org/10.1037/0022-3514.48.6.1413

Isen, A. M., Shalker, T. E., Clark, M. S., \& Karp, L. (1978). Positive Affect, Accessibility of Material in Memory, and Behavior: A Cognitive Loop. Journal of Personality and Social Psychology, 36, 1-12. https://doi.org/10.1037/0022-3514.36.1.1

Isen, A., M., Daubman, K. A., \& Nowicki, G. P. (1987). Positive Affect Facilitates Creative Problem Solving. Journal of Personality and Social Psychology, 52, 1122-1131. https://doi.org/10.1037/0022-3514.52.6.1122

Jehn, K. A., \& Mannix, E. A. (2001). The Dynamic Nature of Conflict: A Longitudinal Study of Intragroup Conflict. Academy of Management Journal, 44, 238-251. 
Jehn, K. A., \& Shah, P. P. (1997). Interpersonal Relationships and Task Performance: An Examination of Mediating Processes in Friendship and Acquaintance Groups. Journal of Personality and Social Psychology, 72, 775-790.

https://doi.org/10.1037/0022-3514.72.4.775

Kelley, H. H. (1966). A Classroom Study of Dilemmas in Interpersonal Negotiations. In K. Archibald (Ed.), Strategic Intervention and Conflict (pp. 49-73). Berkeley, CA: University of California, Institute of International Studies.

Kelley, H. H., \& Thibaut, J. (1978). Interpersonal Relations: A Theory of Interdependence. New York: Academic Press.

Keltner, D., \& Haidt, J. (1999). Social Functions of Emotions at Four Levels of Analysis. Cognition and Emotion, 13, 505-521. https://doi.org/10.1080/026999399379168

Keltner, D., Gruenfeld, D. H., \& Anderson, C. (2003). Power, Approach, and Inhibition. Psychological Review, 110, 265-284. https://doi.org/10.1037/0033-295X.110.2.265

Ketelaar, T., \& Au, W. T. (2003). The Effects of Feelings of Guilt on the Behavior of Uncooperative Individuals in Repeated Social Bargaining Games: An Affect-as-Information Interpretation of the Role of Emotion in Social Interaction. Cognition and Emotion, 17, 429-453. https://doi.org/10.1080/02699930143000662

Kim, P. H. (1997). Strategic Timing in Group Negotiations: The Implications of Forced Entry and Forced Exit for Negotiators with Unequal Power. Organizational Behavior and Human Decision Processes, 71, 263-286. https://doi.org/10.1006/obhd.1997.2722

Kim, P. H., Ferrin, D. L., Cooper, C. D., \& Dirks, K. T. (2004). Removing the Shadow of Suspicion: The Effects of Apology versus Denial for Repairing Competence- versus Integrity-Based Trust Violations. Journal of Applied Psychology, 89, 104-118.

https://doi.org/10.1037/0021-9010.89.1.104

Kimmel, M., Pruitt, D., Magenau, J., Konar-Goldband, E., \& Carnevale, P. (1980). Effects of Trust, Aspiration, and Gender on Negotiation Tactics. Journal of Personality and Social Psychology, 38, 9-22. https://doi.org/10.1037/0022-3514.38.1.9

Knapp, M. L., \& Miller, G. R. (1985). Handbook of Interpersonal Communication. Beverly Hills, CA: Sage.

Koch, B., \& Koch, P. (2007). Collectivism, Individualism, and Outgroup Cooperation in a Segmented China. Asia Pacific Journal of Management, 24, 207-225.

https://doi.org/10.1007/s10490-006-9004-5

Kolb, D. M., \& Williams, J. (2000). The Shadow Negotiation: How Women Can Master the Hidden Agendas That Determine Bargaining Success. New York: Simon \& Schuster.

Komorita, S. S., \& Parks, C. D. (1995). Interpersonal Relations: Mixed Motive Interaction. Annual Review of Psychology, 46, 183-207. https://doi.org/10.1146/annurev.ps.46.020195.001151

Kopelman, S., Rosette, A. S., \& Thompson, L. (2006). The Three Faces of Eve: Strategic Displays of Positive, Negative, and Neutral Emotions in Negotiations. Organizational Behavior and Human Decision Processes, 99, 81-101. https://doi.org/10.1016/j.obhdp.2005.08.003

Kramer, R., Newton, E., \& Pommerenke, L. (1993). Self-Enhancement Biases and Negotiator Judgment: Effects on Self-Esteem and Mood. Organizational Behavior and Human Decision Processes, 56, 110-133. https://doi.org/10.1006/obhd.1993.1047

Kray, L. J., \& Thompson, L. (2005). Gender Stereotypes and Negotiation Performance: An Examination of Theory and Research. Research in Organizational Behavior, 26, 103-182. https://doi.org/10.1016/S0191-3085(04)26004-X 
Kray, L. J., Galinsky, A., \& Thompson, L. (2002). Reversing the Gender Gap in Negotiations: An Exploration of Stereotype Regeneration. Organizational Behavior and Human Decision Processes, 87, 386-409. https://doi.org/10.1006/obhd.2001.2979

Kray, L. J., Thompson, L. L., \& Galinsky, A. (2001). Battle of the Sexes: Gender Stereotype Confirmation and Reactance in Negotiations. Journal of Personality and Social Psychology, 80, 942-958. https://doi.org/10.1037/0022-3514.80.6.942

Kumar, R. (1997). The Role of Affect in Negotiation: An Integrative Overview. Journal of Applied Behavioral Science, 33, 84-100. https://doi.org/10.1177/0021886397331007

Kurtzberg, T. R., Naquin, C. E., \& Belkin, L. Y. (2005). Electronic Performance Appraisals: The Effects of E-Mail Communication on Peer Ratings in Actual and Simulated Environments. Organizational Behavior and Human Decision Processes, 98, 216-226. https://doi.org/10.1016/j.obhdp.2005.07.001

Lanzetta, J. T. (1989). Expectations of Cooperation and Competition and Their Effects on Observers' Vicarious Emotional Responses. Journal of Personality and Social Psychology, 56, 543-554. https://doi.org/10.1037/0022-3514.56.4.543

Lawler, E. J. (1992). Power Processes in Bargaining. The Sociological Quarterly, 33, 17-34. https://doi.org/10.1111/j.1533-8525.1992.tb00361.x

Lawler, E. J., \& Yoon, J. (1995). Structural Power and Emotional Processes in Negotiation. In R. M. Kramer, \& D. M. Messick (Eds.), Negotiation as a Social Process (pp. 143165). Thousand Oaks, CA: Sage. https://doi.org/10.4135/9781483345369.n7

Lawler, E. J., \& Yoon, J. (1996). Commitment in Exchange Relations: Test of a Theory of Relational Cohesion. American Sociological Review, 61, 89-108. https://doi.org/10.2307/2096408

Lee, F., \& Tiedens, L. Z. (2001). Is It Lonely at the Top? The Independence and Interdependence of Power Holders. In B. M. Staw, \& R. I. Sutton (Eds.), Research in Organizational Behavior (Vol. 23, pp. 43-91). New York: JAI Press. https://doi.org/10.1016/S0191-3085(01)23003-2

Lelieveld, G. J., Van Dijk, E., Van Beest, I., \& Van Kleef, G. A. (2012). Why Anger and Disappointment Affect Other's Bargaining Behavior Differently: The Moderating Role of Power and the Mediating Role of Reciprocal and Complementary Emotions. Personality and Social Psychology Bulletin, 38, 1209-1221. https://doi.org/10.1177/0146167212446938

Lelieveld, G., Van Dijk, E., Van Beest, I., Steinel, W., \& Van Kleef, G. (2011). Disappointed in You, Angry about Your Offer: Distinct Negative Emotions Induce Concessions via Different Mechanisms. Journal of Experimental Social Psychology, 47, 635-641. https://doi.org/10.1016/j.jesp.2010.12.015

Lewicki, R. J., Litterer, J. A., Minton, J. W., \& Saunders, D. M. (1994). Negotiation (2nd ed.). Burr Ridge, IL: Richard D. Irwin, Inc.

Lewicki, R. J., Saunders, D. M., \& Barry, B. (2006). Negotiation (5th ed.). Boston, MA: McGraw-Hill.

Lewicki, R. J., Weiss, S. E., \& Lewin, D. (1992). Models of Conflict, Negotiation and Third Party Intervention: A Review and Synthesis. Journal of Organizational Behavior, 13, 209-252. https://doi.org/10.1002/job.4030130303

Liu, M. (2009). The Intrapersonal and Interpersonal Effects of Anger on Negotiation Strategies: A Cross-Cultural Investigation. Human Communication Research, 35, 148 169. https://doi.org/10.1111/j.1468-2958.2008.01342.x

Loewenstein, G., Thompson, L., \& Bazerman, M. H. (1989). Social Utility and Decision Making in Interpersonal Contexts. Journal of Personality and Social Psychology, 57, 
426-441. https://doi.org/10.1037/0022-3514.57.3.426

Lyubomirsky, S., King, L., \& Diener, E. (2005). The Benefits of Frequent Positive Affect: Does Happiness Lead to Success? Psychological Bulletin, 131, 803-855. https://doi.org/10.1037/0033-2909.131.6.803

Mack, R. W., \& Snyder, R. C. (1957). The Analysis of Social Conflict-Toward an Overview and Synthesis. Journal of Conflict Resolution, 1, 212-248. https://doi.org/10.1177/002200275700100208

Magee, J. C., Galinsky, A. D., \& Gruenfeld, D. H. (2007). Power, Propensity to Negotiate, and Moving First in Competitive Interactions. Personality \& Social Psychology Bulletin, 33, 200-212. https://doi.org/10.1177/0146167206294413

Major, B., Vanderslice, V., \& Mcfarlin, D. B. (1984). Effects of Pay Expected on Pay Received: The Confirmatory Nature of Initial Expectations. Journal of Applied Social Psychology, 14, 399-412. https://doi.org/10.1111/j.1559-1816.1984.tb02247.x

Markus, H. R., \& Kitayama, S. (1991). Culture and the Self: Implications for Cognition, Emotion, and Motivation. Psychological Review, 98, 224-253.

https://doi.org/10.1037/0033-295X.98.2.224

Martinez, L. M. F., Zeelenberg, M., \& Rijsman, J. B. (2011). Behavioural Consequences of Regret and Disappointment in Social Bargaining Games. Cognition and Emotion, 25, 351-359. https://doi.org/10.1080/02699931.2010.485889

Marwell, G., \& Schmitt, D. R. (1972). Cooperation in a Three-Person Prisoner's Dilemma. Journal of Personality and Social Psychology, 21, 376-383.

https://doi.org/10.1037/h0032319

Marwell, G., Ratcliff, K., \& Schmitt, D. R. (1969). Minimizing Differences in a Maximizing Difference Game. Journal of Personality and Social Psychology, 12, 158-163. https://doi.org/10.1037/h0027574

Mayer, R. C., \& Davis, J. H. (1999). The Effect of Performance Appraisal Systems on Trust for Management: A Field Quasi-Experiment. Journal of Applied Psychology, 84, 123-136. https://doi.org/10.1037/0021-9010.84.1.123

Mayer, R. C., Davis, J. H., \& Schoorman, F. D. (1995). An Integrative Model of Organizational Trust. Academy of Management Review, 20, 709-724.

https://doi.org/10.5465/amr.1995.9508080335

Miles, E. W., \& Clenney, E. F. (2010). Gender Differences in Negotiation: A Status Characteristics Theory View. Negotiation and Conflict Management Research, 3, 130-144. https://doi.org/10.1111/j.1750-4716.2010.00054.x

Morley, I., \& Stephenson, G. M. (1977). The Social Psychology of Bargaining. London: Allen and Unwin.

Morris, M. W., \& Keltner, D. (2000). How Emotions Work: The Social Functions of Emotional Expression in Negotiations. Research in Organizational Behavior, 22, 1-50. https://doi.org/10.1016/S0191-3085(00)22002-9

Morris, M. W., Larrick, R., \& Su, S. K. (1999). Misperceiving Negotiation Counterparts: When Situationally Determined Bargaining Behaviors Are Attributed to Personality Traits. Journal of Personality and Social Psychology, 77, 52-76. https://doi.org/10.1037/0022-3514.77.1.52

Morris, M. W., Leung, K., \& Sethi, S. (1995). Person Perception in the Heat of Conflict: Perception of Opponents' Traits and Conflict Resolution Choices in Two Cultures. Working Paper Series, Stanford, CA: Graduate School of Business, Stanford University.

Mussel, P., Göritz, A. S., \& Hewig, J. (2013). The Value of a Smile: Facial Expression Affects Ultimatum-Game Responses. Judgment and Decision Making, 8, 381-385. 
Naquin, C. E., \& Paulson, G. D. (2003). Online Bargaining and Interpersonal Trust. Journal of Applied Psychology, 88, 113-120. https://doi.org/10.1037/0021-9010.88.1.113

Nash, J. (1950). The Bargaining Problem. Econometrica, 18, 155-162. https://doi.org/10.2307/1907266

Nash, J. (1951). Non-Cooperative Games. Annals of Mathematics, 54, $286-295$. https://doi.org/10.2307/1969529

Nash, J. (1953). Two-Person Cooperative Games. Econometrica, 21, 129-140. https://doi.org/10.2307/1906951

Neale, M. A., \& Bazerman, M. H. (1985). The Effect of Externally Set Goals on Reaching Integrative Agreements in Competitive Markets. Journal of Occupational Behavior, 6, 19-32. https://doi.org/10.1002/job.4030060103

Neale, M. A., \& Bazerman, M. H. (1992). Negotiator Cognition and Rationality: A behAvioral Decision Theory Perspective. Organizational Behavior and Human Decision Processes, 51, 157-175. https://doi.org/10.1016/0749-5978(92)90009-V

Nelissen, R. A., Leliveld, M., Van Dijk, E., \& Zeelenberg, M. (2011). Fear and Guilt in Proposers: Using Emotions to Explain Offers in Ultimatum Bargaining. European Journal of Social Psychology, 41, 78-85. https://doi.org/10.1002/ejsp.735

Nisbett, R., \& Ross, L. (1980). Human Inference: Strategies and Shortcomings of Social Judgement. Englewood Cliffs, NJ: Prentice Hall.

O’Connor, K. M., \& Carnevale, P. J. (1997). A Nasty But Effective Negotiation Strategy: Misrepresentation of a Common-Value Issue. Personality and Social Psychology Bulletin, 23, 504-517. https://doi.org/10.1177/0146167297235006

O’Connor, K. M., Arnold, J. A., \& Burris, E. R. (2005). Negotiators' Bargaining Histories and Their Effects on Future Negotiation Performance. Journal of Applied Psychology, 90, 350-362. https://doi.org/10.1037/0021-9010.90.2.350

Oatley, K., \& Jenkins, J. M. (1996). Understanding Emotions. Cambridge, MA: Blackwell.

Olekalns, M., \& Druckman, D. (2014). With Feeling: How Emotions Shape Negotiation. Negotiation Journal, 30, 455-478. https://doi.org/10.1111/nejo.12071

Olekalns, M., \& Smith, P. L. (2009). Mutually Dependent: Power, Trust, Affect and the Use of Deception in Negotiation. Journal of Business Ethics, 85, 347-365. https://doi.org/10.1007/s10551-008-9774-4

Overbeck, J. R., Neale, M. A., \& Govan, C. L. (2010). I Feel, Therefore You Act: Intrapersonal and Interpersonal Effects of Emotion on Negotiation as a Function of Social Power. Organizational Behavior and Human Decision Processes, 112, 126-139. https://doi.org/10.1016/j.obhdp.2010.02.004

Pareto, V. (1935). The Mind and Society: A Treatise on General Sociology. New York: Harcourt Brace.

Parks, C. D., \& Komorita, S. S. (1998). Reciprocity Research and Its Implications for the Negotiation Process. International Negotiation, 3, 151-169. https://doi.org/10.1163/15718069820848166

Parks, C. D., Henager, R. F., \& Scamahorn, S. D. (1996). Trust and Messages of Intent in Social Dilemmas. Journal of Conflict Resolution, 40, 134-151. https://doi.org/10.1177/0022002796040001007

Parrott, W. G. (2001). Emotions in Social Psychology: Volume Overview. In W. G. Parrott (Ed.), Emotions in Social Psychology (pp. 1-19). Philadelphia, PA: Psychology Press.

Pietroni, D., Van Kleef, G. A., De Dreu, C. K. W., \& Pagliaro, S. (2008). Emotions as Stra- 
tegic Information: Effects of Other's Emotions on Fixed-Pie Perception, Demands and Integrative Behavior in Negotiation. Journal of Experimental Social Psychology, 44, 1444-1454. https://doi.org/10.1016/j.jesp.2008.06.007

Pietroni, D., Van Kleef, G. A., Rubaltelli, E., \& Rumiati, R. (2009). When Happiness Pays in Negotiation. Mind \& Society, 8, 77-92. https://doi.org/10.1007/s11299-008-0047-9

Pillutla, M. M., \& Murnighan, J. K. (1996). Unfairness, Anger, and Spite: Emotional Rejections of Ultimatum Offers. Organizational Behavior and Human Decision Processes, 68, 208-224. https://doi.org/10.1006/obhd.1996.0100

Pinkley, R. (1990). Dimensions of Conflict Frame: Disputant Interpretations of Conflict. Journal of Applied Psychology, 75, 117-126. https://doi.org/10.1037/0021-9010.75.2.117

Pruitt, D. G. (1981). Negotiation Behavior. New York: Academic Press.

Pruitt, D. G. (1983a). Achieving Integrative Agreements. In M. Bazerman, \& R. Liwicki (Eds.), negotiating in Organizations. Beverly Hills, CA: Sage.

Pruitt, D. G. (1983b). Strategic Choice in Negotiation. American Behavioral Scientist, 27, 167-194. https://doi.org/10.1177/000276483027002005

Pruitt, D. G. (1998). Social Conflict. In D. Gilbert, S. T. Fiske, \& G. Lindzey (Eds.), Handbook of Social Psychology (4th ed., Vol. 2, pp. 470-503). New York: McGraw-Hill.

Pruitt, D. G., \& Carnevale, P. (1982). The Development of Integrative Agreements. In V. J. Derlega, \& J. Brzelak (Eds.), Cooperation and Helping Behavior (pp. 151-181). New York: Academic Press. https://doi.org/10.1016/B978-0-12-210820-4.50012-5

Pruitt, D. G., \& Carnevale, P. J. (1993). Negotiation in Social Conflict. Pacific Grove, CA: Brooks Cole.

Pruitt, D. G., \& Drews, J. L. (1969). The Effect of Time Pressure, Time Elapsed, and the Opponent's Concession Rate on Behavior in Negotiation. Journal of Experimental Social Psychology, 5, 43-60. https://doi.org/10.1016/0022-1031(69)90005-5

Pruitt, D. G., \& Johnson, D. F. (1972). Mediation as an Aid to Face Saving in Negotiation. Journal of Personality and Social Psychology, 14, 239-246. https://doi.org/10.1037/h0028883

Pruitt, D. G., \& Kimmel, M. J. (1977). Twenty Years of Experimental Gaming: Critique, Synthesis, and Suggestions for the Future. Annual Review of Psychology, 28, 363-392. https://doi.org/10.1146/annurev.ps.28.020177.002051

Pruitt, D. G., \& Lewis, S. A. (1977). The Psychology of Integrative Bargaining. In D. Druckman (Ed.), Negotiations: A Social-Psychological Perspective. New York: Halsted. https://doi.org/10.1037/e668292012-310

Pruitt, D., \& Rubin, J. (1986). Social Conflict: Escalation, Stalemate, and Settlement. New York: Random House.

Putnam, L. L., \& Kolb, D. M. (2000). Rethinking Negotiation: Feminist Views of Communication and Exchange. In P. Buzzanell (Ed.), Rethinking Organizational and Managerial Communication from Feminist Perspectives (pp. 76-114). Thousand Oaks, CA: Sage. https://doi.org/10.4135/9781452225494.n4

Raiffa, H. (1982). The Art and Science of Negotiation. Cambridge, MA: Harvard University Press.

Rawwas, M. Y. A., Vitell, S. J., \& Barnes, J. H. (1997). Management of Conflict Using Individual Power Sources: A Retailers' Perspective. Journal of Business Research, 40, 49-64. https://doi.org/10.1016/S0148-2963(96)00210-X

Rhoades, J. A., Arnold, J., \& Jay, C. (2001). The Role of Affective Traits and Affective States in Disputants' Motivation and Behavior during Episodes of Organizational Conflict. Journal of Organizational Behavior, 22, 329-345. https://doi.org/10.1002/job.72 
Ross, L., \& Nisbett, R. E. (1991). The Person and the Situation: Perspectives of Social Psychology. New York: McGraw-Hill.

Rousseau, D. M., Sitkin, S. B., Burt, R. S., \& Camerer, C. (1998). Not So Different after All: A Cross-Discipline View of Trust. Academy of Management Review, 23, 393-404. https://doi.org/10.5465/amr.1998.926617

Rubin, J. Z., \& Brown, B. R. (1975). The Social Psychology of Bargaining and Negotiation. New York: Academic Press.

Schelling, T. (1960). The Strategy of Conflict. Cambridge, MA: Harvard University Press.

Schmidt, K. D. (1979). Doing Business in Taiwan and Doing Business in Japan. Menlo Park, CA: SRI International.

Schwartz, S. H. (1994). Beyond Individualism/Collectivism: New Cultural Dimensions of Values. In U. Kim, H. C. Triandis, \& G. Yoon (Eds.), Individualism and Collectivism (pp. 85-117). London: Sage.

Schweitzer, M. E., Hershey, J. C., \& Bradlow, E. T. (2006). Promises and Lies: Restoring Violated Trust. Organizational Behavior and Human Decision Processes, 101, 1-19. https://doi.org/10.1016/j.obhdp.2006.05.005

Seligman, M. (2002). Authentic Happiness: Using the New Positive Psychology to Realize your Potential for Lasting Fulfillment. New York: Free Press.

Seligman, M. E., \& Csikszentmihalyi, M. (2000). Special Issue on Happiness, Excellence, and Optimal Human Functioning. American Psychologist, 55, 5-183.

Shapiro, D. L. (1991). The Effects of Explanations on Negative Reactions to Deceit. Administrative Science Quarterly, 36, 614-630. https://doi.org/10.2307/2393276

Shapiro, D. L. (2004). Emotions in Negotiation: Peril or Promise? Marquette Law Review, 87, 737-745.

Shapiro, D. L., \& Bies, R. J. (1994). Threats, Bluffs, and Disclaimers in Negotiations. Organizational Behavior and Human Decision Processes, 60, 14-35. https://doi.org/10.1006/obhd.1994.1073

Siegel, S., \& Fouraker, L. (1960). Bargaining Behavior. New York: McGraw-Hill.

Sinaceur, M., \& Tiedens, L. Z. (2006). Get Mad and Get More than Even: When and Why Anger Expression Is Effective in Negotiations. Journal of Experimental Social Psychology, 42, 314-322. https://doi.org/10.1016/j.jesp.2005.05.002

Small, D. A., Gelfand, M., Babcock, L., \& Gettman, H. (2007). Who Goes to the Bargaining Table? The Influence of Gender and Framing on the Initiation of Negotiation. Journal of Personality and Social Psychology, 93, 600-613. https://doi.org/10.1037/0022-3514.93.4.600

Stevens, C. K., Bavetta, A. G., \& Gist, M. E. (1993). Gender Differences in the Acquisition of Salary Negotiation Skills: The Role of Goals, Self-Efficacy, and Perceived Control. Journal of Applied Psychology, 78, 723-735. https://doi.org/10.1037/0021-9010.78.5.723

Stevens, C. M. (1958). On the Theory of Negotiation. The Quarterly Journal of Economics, 72, 77-97. https://doi.org/10.2307/1884190

Stuhlmacher, A. F., \& Walters, A. E. (1999). Gender Differences in Negotiation Outcome: A Meta-Analysis. Personnel Psychology, 52, 653-677. https://doi.org/10.1111/j.1744-6570.1999.tb00175.x

Stuhlmacher, A. F., Citera, M., \& Willis, T. (2007). Gender Differences in Virtual Negotiation: Theory and Research. Sex Roles, 57, 329-339. https://doi.org/10.1007/s11199-007-9252-y

Sullivan, B. A., O’Connor, K. M., \& Burris, E. R. (2006). Negotiator Confidence: The Im- 
pact of Self-Efficacy on Tactics and Outcomes. Journal of Experimental Social Psychology, 42, 567-581. https://doi.org/10.1016/j.jesp.2005.09.006

Thibaut, J. W., \& Kelley, H. H. (1959). The Social Psychology of Groups. New York: Wiley.

Thibaut, J., \& Gruder, C. L. (1969). Formation of Contractual Agreements between Parties of Unequal Power. Journal of Personality and Social Psychology, 11, 59-65. https://doi.org/10.1037/h0027033

Thomas, K. W. (1990). Conflict and Negotiation Processes in Organizations. In M. Dunnote, \& L. M. Hough (Eds.), Handbook of Industrial and Organizational Psychology (2nd ed.). Chicago, IL: Rand McNally.

Thompson, L. (1990). Negotiation Behavior and Outcomes: Empirical Evidence and Theoretical Issues. Psychological Bulletin, 108, 515-532. https://doi.org/10.1037/0033-2909.108.3.515

Thompson, L. (1998). The Mind and Heart of the Negotiator. Upper Saddle River, NJ: Prentice Hall.

Thompson, L. L., Nadler, J., \& Kim, P. H. (1999). Some Like It Hot: The Case for the Emotional Negotiator. In L. L. Thompson, J. M. Levine, \& D. M. Messick (Eds.), Shared Cognition in Organizations: The Management of Knowledge (pp. 139-161). Mahwah, NJ: Erlbaum. https://doi.org/10.4324/9781410603227-7

Thompson, L. L., Wang, J., \& Gunia, B. C. (2010). Negotiation. Annual Review of Psychology, 61, 491-515. https://doi.org/10.1146/annurev.psych.093008.100458

Thompson, L., \& Hastie, R. (1990a). Judgment Tasks and Biases in Negotiation. In B. H. Sheppard, M. H. Bazerman, \& R. J. Lewicki (Eds.), Research in Negotiation in Organizations (Vol. 2, pp. 31-54). Greenwich, CT: JAI Press.

Thompson, L., \& Hastie, R. (1990b). Social Perception in Negotiation. Organizational Behavior and Human Decision Processes, 47, 98-123. https://doi.org/10.1016/0749-5978(90)90048-E

Thompson, L., Valley, K. L., \& Kramer, R. (1995). The Bittersweet Feeling of Success: An Examination of Social Perception in Negotiation. Journal of Experimental Social Psychology, 31, 467-492. https://doi.org/10.1006/jesp.1995.1021

Tickle-Degnen, L., \& Rosenthal, R. (1990). The Nature of Rapport and Its Nonverbal Correlates. Psychological Inquiry, 1, 285-293. https://doi.org/10.1207/s15327965pli0104_1

Triandis, H. C. (1988). Collectivism vs. Individualism: A Reconceptualisation of a Basic Concept in Cross-Cultural Psychology. In G. Verma, \& C. Bagley (Eds.), Cross-Cultural Studies of Personality, Attitudes, and Cognition (pp. 60-95). London: Macmillan. https://doi.org/10.1007/978-1-349-08120-2_3

Tversky, A., \& Kahneman, D. (1981). The Framing of Decisions and the Psychology of Choice. Science, 211, 453-458. https://doi.org/10.1126/science.7455683

Van Dijk, E., Van Kleef, G. A., Steinel, W., \& Van Beest, I. (2008). A Social Functional Approach to Emotions in Bargaining: When Communicating Anger Pays and When It Backfires. Journal of Personality and Social Psychology, 94, 600-614. https://doi.org/10.1037/0022-3514.94.4.600

Van Doorn, E. A., Van Kleef, G. A., \& Van der Pligt, J. (2015). Deriving Meaning from Others' Emotions: Attribution, Appraisal, and the Use of Emotions as Social Information. Frontiers in Psychology, 6, 1077. https://doi.org/10.3389/fpsyg.2015.01077

Van Kleef, G. A. (2008). Emotion in Conflict and Negotiation: Introducing the Emotions as Social Information (EASI) Model. In N. M. Ashkanasy, \& C. L. Cooper (Eds.), Re- 
search Companion to Emotion in Organizations (pp. 392-404). London: Edward Elgar.

Van Kleef, G. A., \& Côté, S. (2018). Emotional Dynamics in Conflict and Negotiation: Individual, Dyadic, and Group Processes. Annual Review of Organizational Psychology and Organizational Behavior, 5, 437-464. https://doi.org/10.1146/annurev-orgpsych-032117-104714

Van Kleef, G. A., \& Van Lange, P. A. M. (2008). What Other's Disappointment May Do to Selfish People: Emotion and Social Value Orientation in a Negotiation Context. Personality and Social Psychology Bulletin, 34, 1084-1095. https://doi.org/10.1177/0146167208318402

Van Kleef, G. A., De Dreu, C. K. W., \& Manstead, A. S. R. (2004). The Interpersonal Effects of Emotions on Negotiations: A Motivated Information Processing Approach. Journal of Personality and Social Psychology, 87, 510-528.

https://doi.org/10.1037/0022-3514.87.4.510

Van Kleef, G. A., De Dreu, C. K. W., \& Manstead, A. S. R. (2006). Supplication and Appeasement in Conflict and Negotiation: The Interpersonal Effects of Disappointment, Worry, Guilt, and Regret. Journal of Personality and Social Psychology, 91, 124-142. https://doi.org/10.1037/0022-3514.91.1.124

Van Kleef, G., \& Côté, S. (2007). Expressing Anger in Conflict: When It Helps and When It Hurts. Journal of Applied Psychology, 92, 1557-1569. https://doi.org/10.1037/0021-9010.92.6.1557

Veitch, R., \& Griffitt, W. (1976). Good News-Bad News: Affective and Interpersonal Effects. Journal of Applied Social Psychology, 6, 69-75. https://doi.org/10.1111/j.1559-1816.1976.tb01313.x

Von Neumann, J., \& Morgenstern, O. (1944). Theory of Games and Economic Behavior. Princeton, NJ: Princeton University Press.

Walters, A. E., Stuhlmacher, A. F., \& Meyer, L. L. (1998). Gender and Negotiator Competitiveness: A Meta-Analysis. Organizational Behavior and Human Decision Processes, 76, 1-29. https://doi.org/10.1006/obhd.1998.2797

Walton, R. E., \& McKersie, R. B. (1965). A Behavioral Theory of Labor Relations. New York: McGraw-Hill.

Wang, L., Northcraft, G. B., \& Van Kleef, G. A. (2012). Beyond Negotiated Outcomes: The Hidden Costs of Anger Expression in Dyadic Negotiation. Organizational Behavior and Human Decision Processes, 119, 54-63. https://doi.org/10.1016/j.obhdp.2012.05.002

Watson, C. (1994). Gender versus Power as a Predictor of Negotiation Behavior and Outcomes. Negotiation Journal, 10, 117-127. https://doi.org/10.1111/j.1571-9979.1994.tb00012.x

Watson, C., \& Hoffman, L. R. (1996). Managers as Negotiators: A Test of Power versus Gender as Predictors of Feelings, Behavior, and Outcomes. The Leadership Quarterly, 7, 63-85. https://doi.org/10.1016/S1048-9843(96)90035-1

Weingart, L. R., Bennet, R. J., \& Brett, J. M. (1993). The Impact of Consideration of Issues and Motivational Orientation on Group Negotiation Process and Outcome. Journal of Applied Psychology, 78, 504-517. https://doi.org/10.1037/0021-9010.78.3.504

Wichman, H. (1970). Effects of Isolation and Communication on Cooperation in a TwoPerson Game. Journal of Personality and Social Psychology, 16, 114-120. https://doi.org/10.1037/h0029845

Wietzker, A., Buysse, A., Loeys, T., \& Brondeel, R. (2012). Easing the Conscience: Feeling Guilty Makes People Cooperate in Divorce Negotiations. Journal of Social and Personal 
Relationships, 29, 324-336. https://doi.org/10.1177/0265407511431180

Zechmeister, K., \& Druckman, D. (1973). Determinants of Resolving a Conflict of Interest. Journal of Conflict Resolution, 17, 63-88.

https://doi.org/10.1177/002200277301700104 